\title{
Komparasi Performa Insulasi Termal Antara Dinding Batu Bata dan Batu Bata dengan Penambahan Insulasi Alang-Alang
}

\author{
${ }^{1}$ Niniek Pratiwi, ${ }^{2}$ Baharuddin Hamzah, ${ }^{3}$ Rosady Mulyadi \\ 1 Universitas Negeri Gorontalo, Gorontalo, (0435) 821125 \\ 2,3 Universitas Hasanuddin, Makassar, (0411) 584200 \\ e-mail: niniek@ung.ac.id
}

\begin{abstract}
Abstrak
Bangunan mengkonsumsi sekitar $40 \%$ dari energi dunia dimulai dari proses pembuatan bangunan itu sendiri sampai bagaimana agar bangunan itu dapat memenuhi kenyamanan termal manusia. Pada zaman dahulu, alang-alang sering digunakan pada bangunan tradisional namun sayangnya saat ini mulai ditinggalkan. Padahal pada beberapa penelitian, alang-alang dapat menurunkan suhu bangunan. Namun pada penelitian tersebut belum meneliti bagaimana alang-alang dijadikan sebagai material insulasi dengan penambahan batu bata sehingga tujuan penelitian ini adalah untuk mengkomparasi performa insulasi termal antara dinding batu bata dan batu bata dengan penambahan insulasi alang-alang. Metode yang digunakan pada penelitian ini adalah dengan menggunakan simulasi Ecotect. Berdasarkan hasil simulasi yang dilakukan diketahui bahwa model 1, yakni dinding batu bata memiliki perbedaan suhu luar dalam sebesar $-1.32917^{\circ} \mathrm{C}$. Artinya rata-rata suhu dalam lebih panas daripada suhu luar sebesar $1.32917^{\circ} \mathrm{C}$. Sementara itu pada model 2, yakni dinding batu bata dengan penambahan insulasi alang-alang memiliki perbedaan suhu luar-dalam sebesar $0.445833^{\circ} \mathrm{C}$. Artinya rata-rata suhu dalam lebih dingin daripada suhu luar sebesar $0.445833^{\circ} \mathrm{C}$. Jadi dapat disimpulkan bahwa alang-alang mampu menjadi material insulasi termal karena memiliki kemampuan untuk menyimpan panas lebih baik dibanding material pada model 1, yakni dinding batu bata.
\end{abstract}

Kata kunci: alang-alang, insulasi, termal

\begin{abstract}
Buildings consume about $40 \%$ of the world's energy, beginning from the process of making the building itself to how the building could meet human thermal comfort needs. In the past, reeds were often used in traditional buildings, but unfortunately these days the practice is being abandoned. Several studies have shown that weeds can reduce building temperatures. However, these studies research has not examined how reeds are used as insulation material along with bricks so the purpose of this study is to compare the thermal insulation performance between plain brick and brick wall with the addition of reed insulation. The method used in this research is to use Ecotect simulation. Based on the results of simulations carried out it is known that model 1, namely the plain brick wall, has an outside-inside temperature difference of $1.32917^{\circ} \mathrm{C}$. This means that the average temperature inside is hotter than the outside temperature by $1.32917^{\circ} \mathrm{C}$. Meanwhile in model 2, the brick wall with the addition of reeds insulation has an outside-inside temperature difference of $0.445833^{\circ} \mathrm{C}$. This means that the average temperature inside is cooler than the outside temperature by $0.445833^{\circ} \mathrm{C}$. Therefore, it can be concluded that reeds could be used as thermal insulation material because it could store heat better than the material in Model 1, which is a plain brick wall.
\end{abstract}

Keywords: reeds, insulation, thermal 


\section{Pendahuluan}

Menurut United Nation Environment Programme dalam Asdrubali et al. (2015), menyatakan bahwa estimasi bangunan mengkonsumsi sekitar $40 \%$ dari energi dunia, $25 \%$ air, $40 \%$ sumber daya global. Bangunan juga bertanggung jawab terhadap $1 / 3$ emisi gas dari efek greenhouse dalam hal ini konsumsi bangunan untuk pendinginan dan pencahayaan.

ASHRAE Standard 55 dan ISO Standard 7730 dalam (Hong et al., 2009) dipergunakan secara luas sebagai standar kenyamanan termal. Kedua standar tersebut berdasarkan model "heat-balance" yang digunakan ke dalam faktor lingkungan seperti suhu, kelembaban, kecepatan udara, faktor personal seperti pakaian dan tingkat aktifitas metabolisme yang dijelaskan oleh Predicted Mean Vote (PMV). Kondisi kenyamanan termal juga diartikan sebagai kenetralan termal, yang berarti bahwa seseorang merasa tidak terlalu dingin atau terlalu panas. Intelektual dan performansi persepsi manusia secara umum mencapai kondisi terbaik bila manusia itu ada dalam kondisi nyaman termal (Fanger, dalam (Sugini, 2014)). Kenyamanan termal selain memegang peran dalam penciptaan kondisi ruang yang nyaman bagi aktivitas, juga berdampak pada kesehatan penghuni bangunan. Apabila suhu badan melebihi $37^{\circ} \mathrm{C}$ dapat mengakibatkan stroke, kelelahan panas dan akhirnya mengantar pada kematian. Bell \& Greene dalam (Sugini, 2014). Menurut Lippsmeir (1994) batas-batas kenyamanan untuk kondisi khatulistiwa adalah pada kisaran suhu udara $22.5^{\circ} \mathrm{C}-29^{\circ} \mathrm{C}$ dengan kelembaban udara $20-50 \%$.

Kulit bangunan adalah komponen penting dalam memanipulasi potensi dan kendala iklim luar untuk mencapai kenyaman termal ruang dalam sesuai tuntutan penghuninya. Menurut Schittich dalam (Asih, 2012), salah satu tugas dari kulit bangunan adalah untuk mengatur kondisi umum di sekeliling atmosfer luar ruang yang bertujuan untuk memastikan kondisi kenyamanan di dalam ruang.

Pada penelitian ini berfokus pada material sebagai kulit bangunan. Di sini dilakukan komparasi performa insulasi termal antara dinding batu bata dan batu bata dengan penambahan insulasi alang-alang. Alang-alang sendiri merupakan material isolasi termal dan akustik yang baik. Hubungan antara ketahanan dan konstruksi adalah kemampuan paling penting dari alang-alang. Kemampuan yang unik dari alangalang telah diketahui sejak lama oleh seluruh dunia. (Lauren, 2000) dalam (Almusaed \& Almssad, 2015). Kendati demikian di beberapa tempat alang-alang ini sendiri hanya dianggap sebagai gulma dan biasanya dibabat dan dibuang ataupun hanya sebagai pakan ternak. Padahal isolator termal yang baik adalah material yang porous. 
Rendahnya konduktivitas termal disebabkan oleh rendahnya konduktivitas udara yang terjebak dalam pori-pori. (Sudirham, 2015).

Beberapa penelitian sebelumnya terkait alang-alang di antaranya di Universitas Estonian, awalnya di Laboratorium Life Science pada kondisi yang tetap yang mana membuktikan bahwa alang-alang lumayan bagus untuk termal propertinya dan cocok dijadikan sebagai material insulasi. (Sterflinger et al., 2013). Kemudian di Indonesia diteliti rumah tradisional Uma Kbubu di Timor Tengah dimana rumah tradisional tersebut menggunakan atap dari alang-alang. Atap ini mendominasi bentuk dari bangunan dan mampu menahan panas dari dalam ke luar ruangan pada musim hujan serta menahan panas dari luar ke dalam bangunan pada musim kemarau. (Suwantara \& Rini, 2011). Sementara itu pada rumah tradisional Uma Lengge di desa Mbawa, Nusa Tenggara Barat menunjukkan dari segi termal statik adalah cukup nyaman untuk ditempati dan sangat responsif terhadap perubahan iklim. Hal ini terlihat dari respon rumah yang dapat menaikkan dengan adanya kenaikan suhu ruangan sebesar 0.1 $0.8^{\circ} \mathrm{C}$ pada saat kondisi suhu luar yang rendah dan menurunkan penurunan suhu ruangan sebesar $0.6-1.8^{\circ} \mathrm{C}$ pada saat kondisi suhu luar yang tinggi. (Suwantara \& Dawayanti, 2012). Penelitian yang lain juga menggabungkan Standard Portland Cement (CEM) dan bilah yang terbuat dari alang-alang yang diambil dari Fert Lake Reed Company digunakan untuk penelitian ini. Papan insulasi menunjukkan hasil yang bagus pada pengujian konduktivitas termal (Alpara et al., 2012).

Dan berdasarkan hasil penelitian yang pernah dilakukan sebelumnya oleh peneliti yang dilakukan di kampus teknik Universitas Hasanuddin Gowa didapatkan bahwa alang-alang dapat menjadi insulasi termal dibandingkan tanpa insulasi. Alangalang dapat menjadi insulasi termal terutama ketika hari terpanas atau hottest day. (Pratiwi, dkk., 2019).

Dari hasil penelitian tersebut, maka dilakukan penelitian lebih lanjut yakni untuk mengkomparasi performa insulasi termal antara dinding batu bata dan batu bata dengan penambahan alang-alang.

\section{Metode}

Metode yang dilakukan adalah dengan menggunakan simulasi dengan Software Ecotect. Software Ecotect menjadi pilihan yang cukup signifikan dan lebih mudah diterapkan, karena software ini memiliki sejumlah fitur-fitur simulasi yang ramah pengguna. Ecotect merupakan software analisa bangunan yang paling inovatif saat ini, yang mengintegrasikan pemodelan $3 d$ dengan berbagai analisa dan simulasi performa bangunan. Berbagai fitur analisa dan simulasi diaplikasikan secara interaktif, setiap perubahan pada desain secara interaktif dapat terbaca dampaknya. Proses simulasi 
dilakukan melalui Autodesk Ecotect 2011 dengan pertimbangan software ini telah banyak dipergunakan dalam simulasi termal serta software ini dapat digunakan secara gratis.

Bangunan yang dijadikan model untuk disimulasi adalah bangunan dengan ukuran $2,4 \mathrm{~m} \times 2,4 \mathrm{~m}$ dengan tanpa bukaan baik pintu ataupun jendela seperti pada gambar 1.

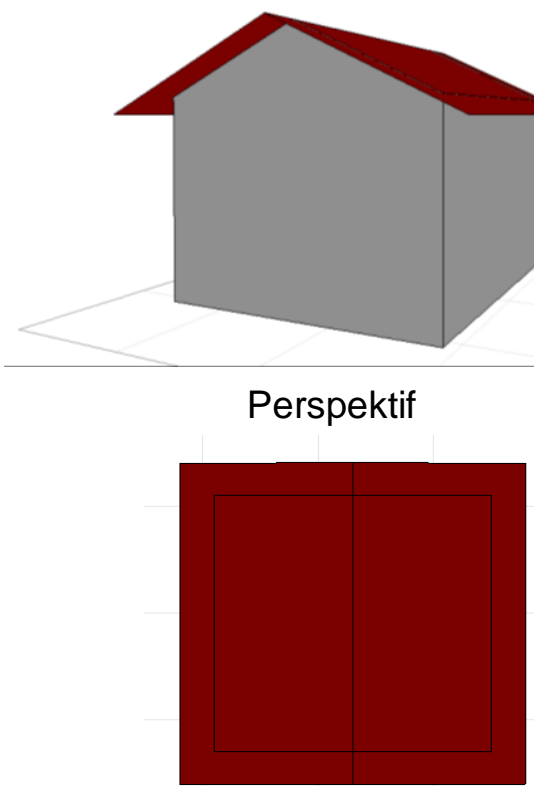

Tampak atas

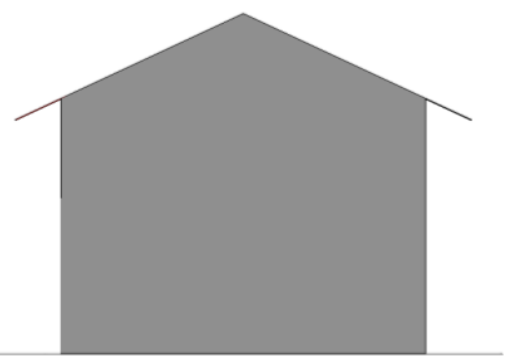

Tampak depan dan belakang

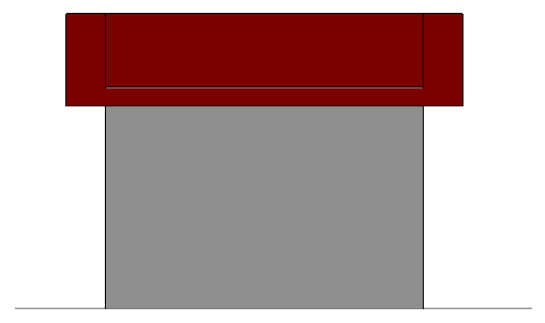

Tampak samping

Gambar 1. Model bangunan yang disimulasikan

Ada 2 model yang disimulasikan, pertama bangunan dengan material batu-bata dengan plesteran yang umum digunakan sebagai material bangunan saat ini dan bangunan kedua dengan material batu bata dengan penambahan insulasi alang-alang. Agar mendapatkan variabel terikat, maka dilakukan penyamaan ketebalan dinding antara dinding pada simulasi 1 dan simulasi 2, dengan total ketebalan dinding yang dipergunakan yakni $12 \mathrm{~cm}$. Oleh karena itu, pada simulasi 2 ketebalan dinding batu bata menjadi $6 \mathrm{~cm}$.

\section{Simulasi 1: Dinding Batu Bata}

Model simulasi 1 yakni dinding batu bata dengan total ketebalan dinding $12 \mathrm{~cm}$ dengan dimensi dan potongan seperti pada gambar 2 dan gambar 3 . 


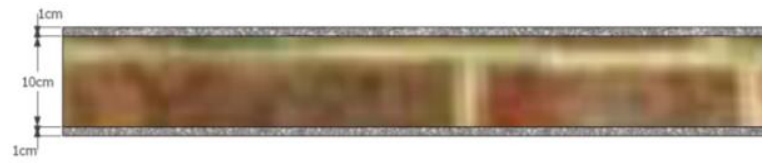

Gambar 2. Dimensi model simulasi 1

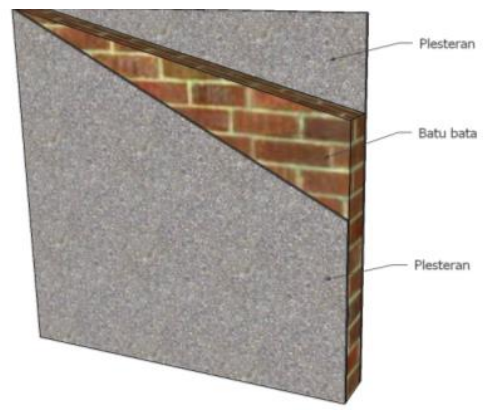

Gambar 3. Potongan model simulasi 2

Nilai property material menggunakan bawaan ecotect itu sendiri seperti tampak pada gambar 4 .

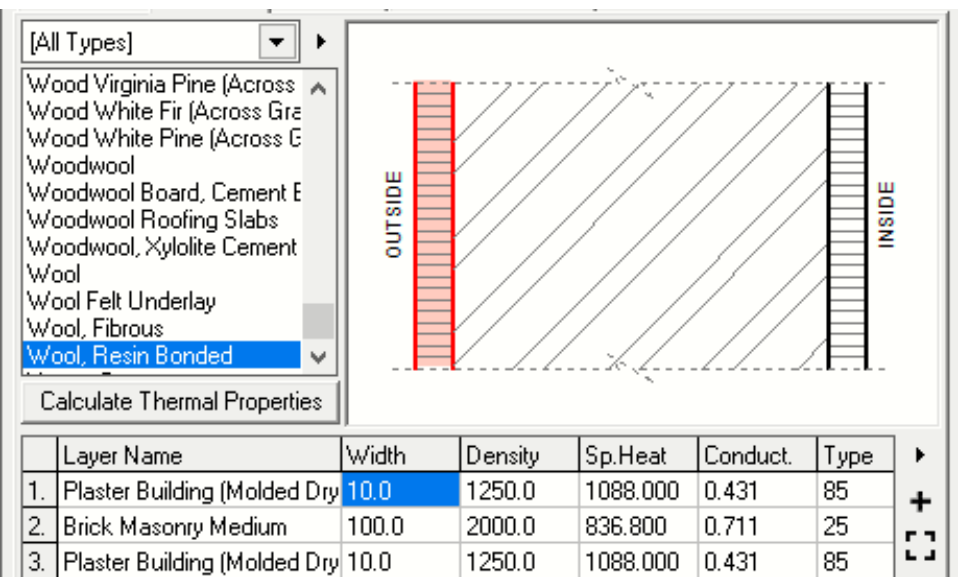

Gambar 4. Property material model simulasi 1 (analisis simulasi ecotect)

\section{Simulasi 2: Dinding Batu Bata dengan Penambahan Insulasi Alang-Alang}

Model simulasi 2 yakni dinding batu bata dengan ketebalan batu bata $6 \mathrm{~cm}$ dan penambahan insulasi alang-alang dengan ketebalan $4 \mathrm{~cm}$ kemudian dilapisi kalsiboard dan plesteran sehingga total dinding ini sebesar $12 \mathrm{~cm}$, sama seperti ketebalan dinding batu bata pada model simulasi 1 dengan dimensi dan potongan seperti pada gambar 5 dan 6.

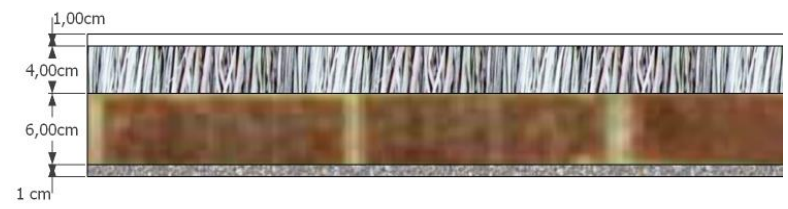

Gambar 5. Dimensi model simulasi 2

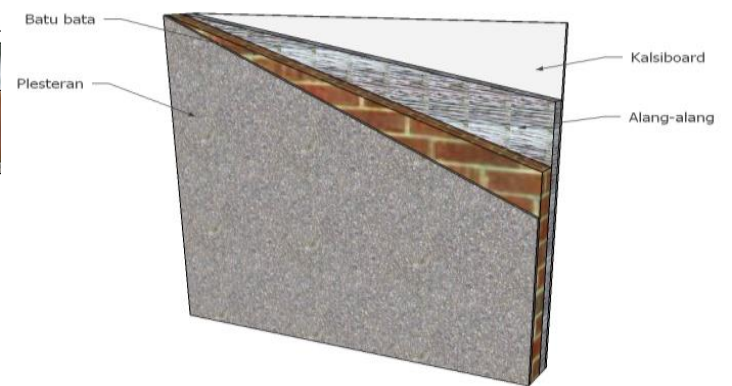

Gambar 6. Potongan model simulasi 2 
Nilai property material batu bata dan plesterannya menggunakan bawaan ecotect itu sendiri. Nilai alang-alang diambil dari hasil penelitian sebelumnya yakni nilai spesifik heat $1200 \mathrm{~J} / \mathrm{kg}^{\circ} \mathrm{C}$ dan konduktivitas termal 0,045 W/m ${ }^{\circ} \mathrm{C}$ (Pratiwi,dkk., 2019) seperti tampak pada gambar 7 .

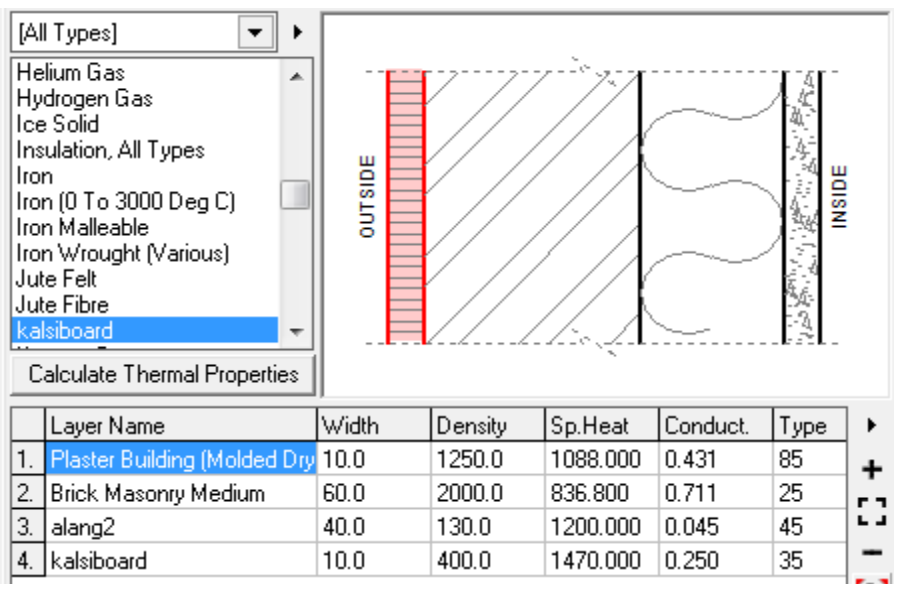

Gambar 7. Property material model simulasi 2 (analisis simulasi ecotect)

\section{Hasil dan Pembahasan}

Berdasarkan simulasi dengan menggunakan Software Ecotect pada kedua model tersebut, maka didapatkan hasil sebagai berikut:

\section{Hasil}

\section{Simulasi 1: Dinding Batu Bata}

Pada model 1, yakni dinding batu bata didapatkan hasil simulasi seperti berikut :

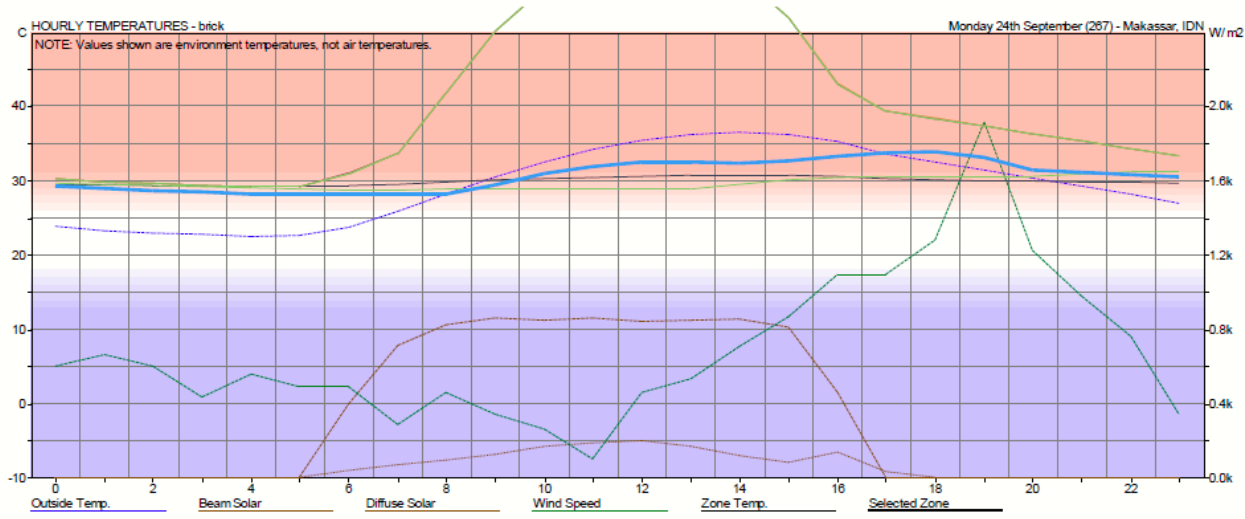

Gambar 8. Grafik kenyamanan termal dinding batu bata (analisis simulasi ecotect)

Zone: brick

Avg. Suhue: $28.1 \mathrm{C}$ (Ground 27.1 C)

Total Surface Area: $34.560 \mathrm{~m} 2$ (600.0\% flr area).

Total Exposed Area: $23.040 \mathrm{~m} 2$ (400.0\% flr area).

Total North Window: $0.000 \mathrm{~m} 2(0.0 \%$ flr area $)$.

Total Window Area: $0.000 \mathrm{~m} 2$ (0.0\% flr area). 
Total Conductance (AU): $49 \mathrm{~W} /{ }^{\circ} \mathrm{K}$

Total Admittance (AY): $118 \mathrm{~W} /{ }^{\circ} \mathrm{K}$

Response Factor: 2.36

Tabel 1 Suhu simulasi model 1: dinding batu bata pada hottest day (peak)

\begin{tabular}{lcccc}
\hline HOUR & INSIDE & $\begin{array}{c}\text { OUTSIDE } \\
\left({ }^{\circ} \mathrm{C}\right)\end{array}$ & \multicolumn{2}{c}{ TEMP.DIF } \\
& $\left({ }^{\circ} \mathrm{C}\right)$ & Dalam-Luar $\left({ }^{\circ} \mathrm{C}\right)$ & Luar-Dalam $\left({ }^{\circ} \mathrm{C}\right)$ \\
\hline 0 & 29.2 & 23.8 & 5.4 & -5.4 \\
1 & 28.9 & 23.2 & 5.7 & -5.7 \\
2 & 28.6 & 23 & 5.6 & -5.6 \\
3 & 28.4 & 22.7 & 5.7 & -5.7 \\
4 & 28.3 & 22.5 & 5.8 & -5.8 \\
5 & 28.2 & 22.6 & 5.6 & -5.6 \\
6 & 28.1 & 23.7 & 4.4 & -4.4 \\
7 & 28.1 & 25.8 & 2.3 & -2.3 \\
8 & 28.2 & 28.2 & 0 & 0 \\
9 & 29.5 & 30.5 & -1 & 1 \\
10 & 31 & 32.5 & -1.5 & 1.5 \\
11 & 31.8 & 34.2 & -2.4 & 2.4 \\
12 & 32.4 & 35.4 & -3 & 3 \\
13 & 32.5 & 36.2 & -3.7 & 3.7 \\
14 & 32.4 & 36.5 & -4.1 & 4.1 \\
15 & 32.7 & 36.2 & -3.5 & 3.5 \\
16 & 33.3 & 35.2 & -1.9 & 1.9 \\
17 & 33.8 & 33.6 & 0.2 & -0.2 \\
18 & 33.9 & 32.5 & 1.4 & -1.4 \\
19 & 33.2 & 31.4 & 1.8 & -1.8 \\
20 & 31.4 & 30.3 & 1.1 & -1.1 \\
21 & 31.1 & 29.2 & 1.9 & -1.9 \\
22 & 30.8 & 28.1 & 2.7 & -2.7 \\
23 & 30.4 & 27 & 3.4 & -3.4 \\
\hline Total & & & & -31.9 \\
Selisih rata-rata & & & -1.32917 \\
\hline
\end{tabular}

Dari hasil simulasi pada model 1 didapatkan pada hari hottest day (peak) yakni pada tanggal 24 September, rentang suhu dalam ruangan berkisar $28,1-33,9^{\circ} \mathrm{C}$ sementara suhu luar ruangan berkisar $22.5-36.5^{\circ} \mathrm{C}$. Dari hasil tersebut bisa diketahui bahwa suhu yang memenuhi standar kenyamanan termal menurut Lippsmeir (1994) hanya sampai di pukul 08.00 , yakni $28,2^{\circ} \mathrm{C}$. Setelah pukul 08.00 , suhu melebihi standar kenyamanan termal bahkan hingga pukul 23.00. Pada pukul 00.00-07.00 suhu di luar lebih rendah daripada suhu di dalam raungan. Pada pukul 09.00-16.00 suhu di luar lebih tinggi daripada suhu di dalam ruangan. Dan pada pukul 17.00-23.00 suhu di luar lebih rendah daripada suhu di dalam ruangan. Dari hasil tersebut juga bisa dilihat dinding batu bata memiliki rata-rata perbedaan suhu udara antara luar-dalam senilai $-1.32917^{\circ} \mathrm{C}$. Artinya rata-rata suhu udara di dalam lebih panas sebesar $1.32917^{\circ} \mathrm{C}$ 
dibanding suhu di luar.Hal ini terjadi karena adanya pengaruh kemampuan bahan dalam menyimpan panas dalam hal ini dinding batu bata.

\section{Simulasi 2: Dinding Batu Bata dengan Penambahan Insulasi Alang-Alang}

Pada model 2, yakni dinding batu bata dengan penambahan insulasi alang-alang didapatkan hasil simulasi seperti gambar 9

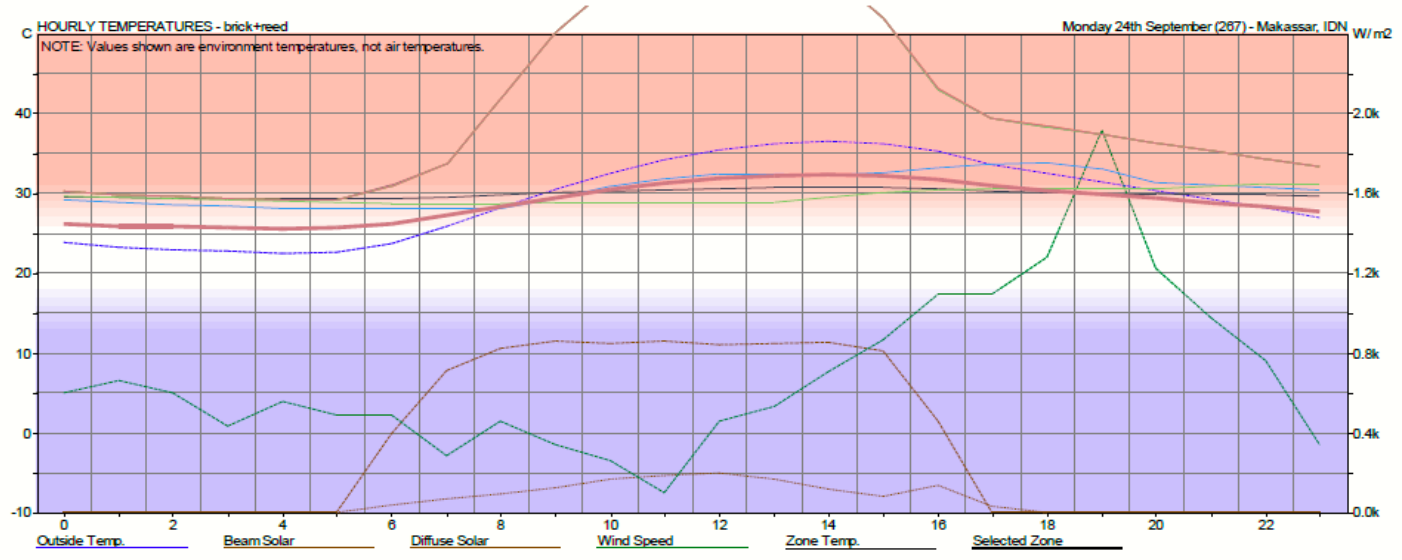

Gambar 9. Grafik kenyamanan termal dinding batu bata (analisis simulasi ecotect)

HOURLY SUHUES - Monday 24th September (267)

Zone: brick+reed

Avg. Suhue: $28.1 \mathrm{C}$ (Ground $27.1 \mathrm{C}$ )

Total Surface Area: $34.560 \mathrm{~m} 2(600.0 \%$ flr area).

Total Exposed Area: $23.040 \mathrm{~m} 2$ (400.0\% flr area).

Total North Window: $0.000 \mathrm{~m} 2(0.0 \%$ flr area $)$.

Total Window Area: $0.000 \mathrm{~m} 2(0.0 \%$ flr area).

Total Conductance (AU): $129 \mathrm{~W} /{ }^{\circ} \mathrm{K}$

Total Admittance (AY): $270 \mathrm{~W} /{ }^{\circ} \mathrm{K}$

Response Factor: 2.07

Tabel 2 Suhu simulasi model 2: dinding batu bata dengan penambahan insulasi alangalang pada hottest day (peak)

\begin{tabular}{lclcc}
\hline HOUR & INSIDE & OUTSIDE & \multicolumn{2}{c}{ TEMP.DIF } \\
& $\left({ }^{\circ} \mathrm{C}\right)$ & $\left({ }^{\circ} \mathrm{C}\right)$ & Dalam-Luar $\left({ }^{\circ} \mathrm{C}\right)$ & Luar-Dalam $\left({ }^{\circ} \mathrm{C}\right)$ \\
\hline 0 & 26.2 & 23.8 & 2.4 & -2.4 \\
1 & 25.9 & 23.2 & 2.7 & -2.7 \\
2 & 25.8 & 23 & 2.8 & -2.8 \\
3 & 25.7 & 22.7 & 3 & -3 \\
4 & 25.6 & 22.5 & 3.1 & -3.1 \\
5 & 25.6 & 22.6 & 3 & -3 \\
6 & 26.2 & 23.7 & 2.5 & -2.5 \\
7 & 27.2 & 25.8 & 1.4 & -1.4 \\
8 & 28.3 & 28.2 & 0.1 & -0.1 \\
9 & 29.5 & 30.5 & -1 & 1 \\
10 & 30.4 & 32.5 & -2.1 & 2.1 \\
11 & 31.3 & 34.2 & -2.9 & 2.9 \\
12 & 31.9 & 35.4 & -3.5 & 3.5 \\
13 & 32.3 & 36.2 & -3.9 & 3.9
\end{tabular}




\begin{tabular}{lcccc}
\hline HOUR & $\begin{array}{l}\text { INSIDE } \\
\left({ }^{\circ} \mathrm{C}\right)\end{array}$ & $\begin{array}{c}\text { OUTSIDE } \\
\left({ }^{\circ} \mathrm{C}\right)\end{array}$ & \multicolumn{2}{c}{ TEMP.DIF } \\
& 32.4 & 36.5 & -4.1 & 4.1 \\
14 & 32.2 & 36.2 & -4 & 4 \\
15 & 31.7 & 35.2 & -3.5 & 3.5 \\
16 & 30.9 & 33.6 & -2.7 & 2.7 \\
17 & 30.4 & 32.5 & -2.1 & 2.1 \\
18 & 29.9 & 31.4 & -1.5 & 1.5 \\
19 & 29.3 & 30.3 & -1 & 1 \\
20 & 28.8 & 29.2 & -0.4 & 0.4 \\
21 & 28.3 & 28.1 & 0.2 & -0.2 \\
22 & 27.8 & 27 & 0.8 & -0.8 \\
23 & & & & 10.7 \\
\hline Total & & & 0.445833 \\
Selisih rata-rata
\end{tabular}

Dari hasil simulasi pada model 2 didapatkan pada hari hottest day (peak) yakni pada tanggal 24 September, rentang suhu dalam ruangan berkisar $25.6-32.4^{\circ} \mathrm{C}$ sementara suhu luar ruangan berkisar $22.5-36.5^{\circ} \mathrm{C}$. Dari hasil tersebut bisa diketahui bahwa suhu yang memenuhi standar kenyamanan termal menurut Lippsmeir(1994) hanya sampai dipukul 08.00 , yakni $28,3^{\circ} \mathrm{C}$. Setelah pukul 08.00 , suhu melebihi standar kenyamanan termal hingga pukul 20.00 dan pada pukul 21.00-23.00 suhu dalam ruangan kembali memenuhi standar kenyamanan dengan suhu berkisar $27,8-28,8^{\circ} \mathrm{C}$. Pada pukul 00.00-08.00 suhu luar lebih rendah daripada suhu dalam raungan. Pada pukul 09.00-21.00 suhu luar lebih tinggi daripada suhu dalam ruangan. Dan pada pukul 22.00-23.00 suhu luar lebih rendah daripada suhu dalam ruangan. Dari hasil tersebut juga bisa dilihat dinding batu bata dengan penambahan insulasi alang-alang memiliki rata-rata perbedaan suhu udara antara luar-dalam senilai $0.445833^{\circ} \mathrm{C}$. Artinya rata-rata suhu dalam ruang lebih dingin sebesar $0.445833^{\circ} \mathrm{C}$. Hal ini terjadi karena adanya pengaruh kemampuan bahan dalam menyimpan panas dalam hal ini dinding batu bata dengan penambahan insulasi alang-alang.

\section{Pembahasan}

Berdasarkan hasil dari simulasi pada kedua model tersebut, dibuat grafik gabungan untuk mengkomparasi suhu dalam ruangan masing-masing model yang bisa dilihat pada gambar 10 .

Dari grafik tersebut terlihat pada hari hottest day (peak) yakni pada tanggal 24 September, dengan suhu luar ruangan yang sama (outside) didapatkan 2 model line masing-masing model simulasi. 


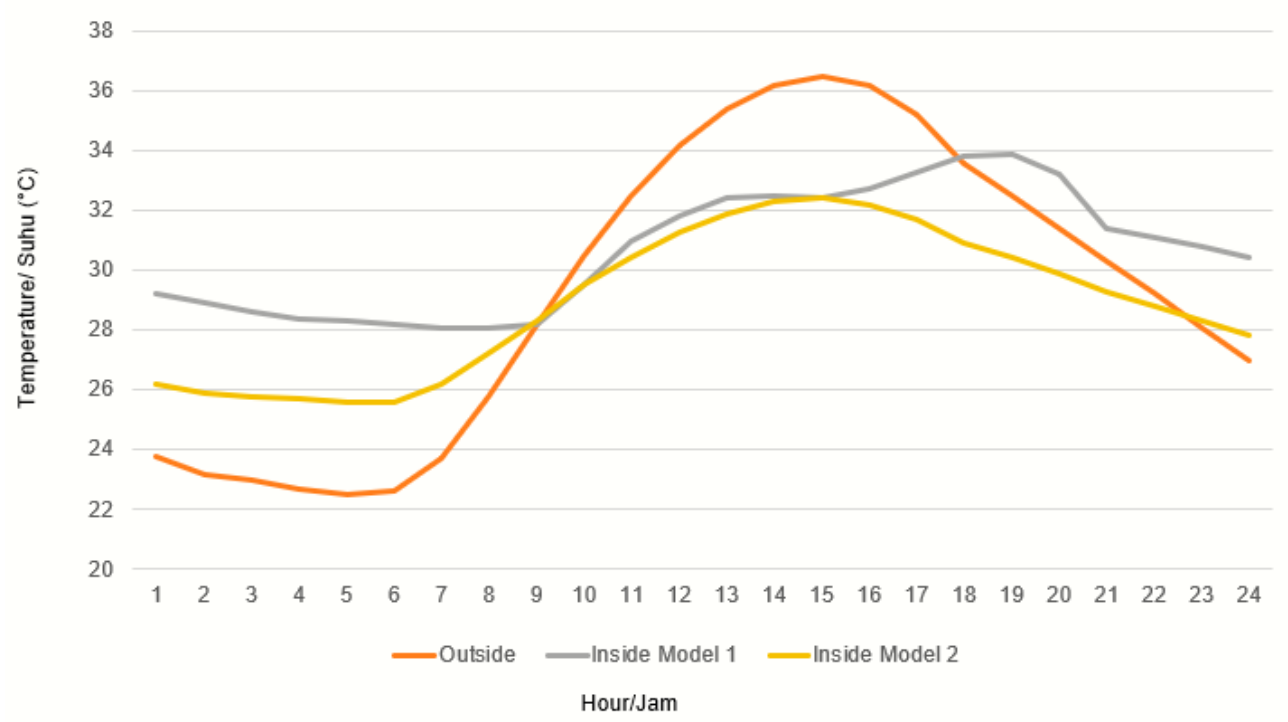

Gambar 10. Grafik komparasi antara suhu luar ruangan dan suhu dalam ruangan pada model 1 dan model 2

Grafik 10 menunjukkan bahwa adanya perbedaan yang signifikan antara suhu luar ruangan dan suhu dalam ruangan masing-masing model simulasi. Hal ini terlihat pada pukul 01.00-08.00 suhu luar ruangan lebih rendah dari kedua suhu di dalam ruangan dengan kisaran suhu $22-28^{\circ} \mathrm{C}$, dan suhu masing-masing di dalam ruangan yakni pada model 1 berkisar $28-30^{\circ} \mathrm{C}$ sementara suhu dalam ruangan model 2 berkisar $26-28^{\circ} \mathrm{C}$. Sementara itu pada pukul 09.00 suhu luar ruangan mulai naik dengan puncak terpanas berada di pukul 14.00-15.00 dengan suhu berkisar $36^{\circ} \mathrm{C}$. Sementara itu untuk suhu dalam ruangan model 1 pada pukul 09.00 suhu dalam ruangan juga naik dan sempat mempertahankan suhunya di pukul 12.00-15.00 dengan kisaran suhu $32^{\circ} \mathrm{C}$ setelahnya suhunya naik lagi dengan puncak terpanas berada di pukul 18.00 dengan suhu sekitar $33^{\circ} \mathrm{C}$ setelahnya suhu dalam ruangan model 1 berangsur-angsur turun. Dan untuk suhu dalam ruangan model 2, pada pukul 09.00 suhu dalam ruangannya juga ikut naik dan mencapai puncak pada pukul 14.00 dengan kisaran suhu $32^{\circ} \mathrm{C}$ setelahnya suhu dalam ruangan model 2 berangsur-angsur turun.

Berdasarkan hasil tersebut bisa dilihat bahwa suhu dalam ruangan pada model 1 lebih tinggi dibanding suhu dalam ruangan pada model 2. Suhu dalam ruangan pada model 2 lebih mampu mempertahankan suhunya sehingga tidak terjadi kenaikan suhu lagi seperti pada suhu dalam ruangan model 1. Hal ini bisa dikarenakan pengaruh dari kulit bangunan yakni bahan yang digunakan. Pengaruh kemampuan bahan untuk menyimpan panas (dalam hal ini dinding) berperan. Saat ada kenaikan suhu udara luar, dinding menyerap kelebihan panasnya. Bila dinding tidak mampu menyimpan panas yang mengalir masuk terus menerus, maka panas menembus dinding dan 
keluar dari permukaan dinding bagian dalam ruang yang suhu udaranya lebih rendah. Bila kemudian suhu udara luar turun menjadi lebih rendah dari suhu permukaan luar dinding, panas mengalir balik keluar dari dinding.

\section{Kesimpulan}

Berdasarkan hasil simulasi yang dilakukan diketahui bahwa model 1, yakni dinding batu bata memiliki perbedaan suhu luar - dalam sebesar $-1.32917^{\circ} \mathrm{C}$. Artinya rata-rata suhu dalam lebih panas daripada suhu luar sebesar $1.32917^{\circ} \mathrm{C}$. Sementara itu pada model 2, yakni dinding batu bata dengan penambahan insulasi alang-alang memiliki perbedaan suhu luar-dalam sebesar $0.445833^{\circ} \mathrm{C}$. Artinya rata-rata suhu dalam lebih dingin daripada suhu luar sebesar $0.445833^{\circ} \mathrm{C}$. Sehingga bisa dikatakan material pada model 2, yakni dinding batu bata dengan penambahan insulasi alangalang memiliki kemampuan untuk menyimpan panas lebih baik dibanding material pada model 1, yakni dinding batu bata.

Jadi dapat disimpulkan bahwa alang-alang mampu menjadi material insulasi termal yang dibuktikan dengan menggunakan simulasi ecotect yang membandingkan antara dinding batu bata dan batu bata dengan penambahan insulasi alang-alang.

\section{Daftar Pustaka}

Almusaed, A. \& Almssad, A. (2015). Building materials in eco-energy houses from Iraq and Iran. Case Studies in Construction Materials, 2, 42-54. Retrieved from https://www.sciencedirect.com/science/article/pii/S2214509515000029.

Alpára,T., Schlosser, M., Hajdu, I \& Bejóa, L. (2012). Developing building materials from cement-bonded reed composite based on waste materials. International Scientific Conference On Sustainable Development \& Ecological Footprint.

Asdrubali, F., D’Alessandro, F., \& Schiavoni, F. (2015). A review of unconventional sustainable building insulation materials. Sustainable Materials and Technologies, 4, 17-34. Retrieved from https://www.sciencedirect.com/science/article/pii/S2214993715000068.

Asih, D. S. (2012). Pengaruh material pelapis pada fasade bangunan terhadap nilai ottv. Magister Thesis, Universitas Indonesia.

Hong, S. H., Gilbertson, J., Oreszczyn, T., Green, G. \& Ridley, I. (2009). A field study of thermal comfort in low-income dwellings in England before and ater energy efficient refurbishment. Building and Environment, 44, 1228-1236.

Pratiwi, N., Hamzah, B., \& Mulyadi, R. (2019). Alang-alang sebagai material insulasi termal. Smart: Seminar on Architecture Research and Technology, 2, 3-12. Retrieved from https://smartfad.ukdw.ac.id/index.php/smart/article/view/74. 
Sterflinger, K., Ettenauer, J., \& Pinar, G. (2013). Bio-susceptibility of materials and thermal insulation systems used for historical buildings. Energy Procedia, 40, 499-506.

Retrieved from

https://www.sciencedirect.com/science/article/pii/S1876610213016512

Sudirham. (2015). Sifat-sifat termal. Retrieved from www.darpublic.com.

Sugini, D. (2014). Kenyamanan termal ruang. Yogyakarta: Graha IImu.

Suwantara, K. \& Dawayanti. (2012). Karakteristik termal pada Uma Lengge di Desa Mbawa Nusa Tenggara Barat. Denpasar: Balai Pengembangan Teknologi Perumahan Tradisional Denpasar, Puslitbang Permukiman Badan Litbang Kementerian Pekerjaan Umum.

Suwantara, K. \& Rini, N. (2011). Kinerja termal rumah tradisional Uma Kbubu. Denpasar: Balai Pengembangan Teknologi Perumahan Tradisional Denpasar, Puslitbang Permukiman Badan Litbang Kementerian Pekerjaan Umum. 